\title{
RANCANG BANGUN APLIKASI E-VOTING BERBASIS WEB PADA PEMILIHAN KETUA DAN WAKIL KETUA OSIS DI SMK IBNU KHOLDUN AL HASYIMI
}

\author{
Firman Jaya $^{1}$, Dyan Yuliana ${ }^{2}$, Kholidy $^{3}$ \\ ${ }^{1,2,3}$ STKIP PGRI Situbondo, Indonesia \\ altamis1922@gmail.com
}

\begin{abstract}
The process of selecting the Chair and Deputy Chairperson of the Student Council at SMK Ibnu Kholdun Al Hasyimi is still conventional, so it requires many funds to be spent. Also, many students cannot contribute their voting rights because they cannot attend due to illness or other reasons. Along with the development of sophisticated technology in modern times, researchers want to implement websitebased elections or what is called e-voting. This study aims to design a web-based e-voting application and test the feasibility of an e-voting application product in the election of the student council chairman and vice-chairman. The PHP MYSQLbased E-voting application developed using the Prototype method can simplify selection, reduce data manipulation, reduce voting twice, and speed up calculations and reporting. Based on the results of the black box testing on the e-voting system, the test was successful, so that it could be implemented in the process of selecting the Student Council Chair and Vice-Chair at Ibnu Kholdun Al Hasyimi Vocational School. The feasibility test was conducted by seven voters/users. The feasibility level of the web-based e-voting system was $84.17 \%$ which means it is very feasible.
\end{abstract}

Keywords: Design, E-Voting, Web, Student Council Selection.

\begin{abstract}
Abstrak: Proses pemilihan Ketua dan Wakil Ketua Osis di SMK Ibnu Kholdun Al Hasyimi masih bersifat konvensional, sehingga membutuhkan banyak dana yang harus dikeluarkan. Selain itu banyak siswa yang tidak bisa menyumbangkan hak suaranya karena tidak bisa hadir dengan alasan sakit atau lain hal. Seiring perkembangan teknologi yang canggih di zaman yang modern ini peneliti ingin mengimplementasikan pemilihan umum yang berbasis website atau yang disebut dengan $e$-voting. Penelitian ini bertujuan untuk merancang aplikasi $e$-voting bebasis web dan menguji kelayakan produk aplikasi $e$-voting dalam pemilihan ketua dan wakil ketua OSIS. Aplikasi E-voting yang berbasis PHP MYSQL yang dikembangkan menggunakan metode Prototype dapat mempermudah pemilihan, mengurangi pemanipulasian data, mengurangi pemilihan 2 kali dan serta mempercepat perhitungan dan pelaporan. Berdasarkan dari hasil pengujian black box testing pada sistem e-voting menyatakan uji coba berhasil, sehingga dapat diimplementasikan pada proses pemilihan Ketua dan Wakil Ketua OSIS di SMK Ibnu Kholdun Al Hasyimi. Uji coba kelayakan yang dilakukan oleh 7 orang pemilih/user. Tingkat kelayakan sistem $e$-voting berbasis web mendapat angka sebesar $84,17 \%$ yang berarti sangat layak.
\end{abstract}

Kata Kunci: Rancang bangun, E-Voting, Web, Pemilihan OSIS. 


\section{PENDAHULUAN}

Seiring dengan pesatnya perkembangan teknologi di era globalisasi modern ini, banyak hal yang harus kita ketahui dan pelajari untuk memanfaatkan teknologi tersebut. Perkembangan teknologi ini sangat berpengaruh pada kehidupan manusia pada zaman sekarang, karena teknologi sudah berkembang bukan hanya di kota melainkan sudah meluas ke pelosok desa dan mempengaruhi banyak masyarakat.

Kebanyakan pemungutan suara atau voting di Indonesia, khususnya pada pemilihan umum (PEMILU) legislatif maupun pemilihan eksekutif, pemilihan kepala desa sampai pemilihan di jenjang pendidikan yaitu pemilihan ketua dan wakil ketua Osis, masih menggunakan metode pemungutan suara konvensional.

Proses penghitungan suara yang berjalan lambat mengakibatkan proses tersebut harus menunggu semua kartu suara terkumpul terlebih dahulu, sehingga memperlambat penghitungan suara. Untuk mengatasi permasalahan di atas salah satu solusi yang dapat diterapkan adalah dengan menyelenggarakan pemilihan secara online atau yang lebih dikenal dengan istilah electronic voting atau e-voting. Proses pemilihan ketua dan wakil ketua Osis di SMK Ibnu Kholdun Al Hasyimi masih bersifat konvensional, proses ini terlalu banyak dana yang harus dikeluarkan dan juga banyak siswa/siswi yang tidak bisa menyumbangkan hak suaranya dikarenakan sakit atau tidak bisa hadir karena alasan sesuatu hal.

Ismail (2017) melakukan penelitian yang berjudul "Aplikasi E-Voting pemilihan Kepala Desa Di Kecamatan Botupingge Berbasis Web", penelitian ini menjabarkan use case dan rancangan sistem dan tampilan dari sistem e-voting, peneliti disinibertujuan untuk mengurangi banyaknya kesalahan yang disebabkan oleh human error.

Ikhwani (2018) dengan judul penelitian “Analisis Dan Rancangan Sistem EVoting Pemilihan Ketua Osis", hasil penelitian tersebut aplikasi menggunakan PHP/WEB Browser yang mana dapat digunakan di laboratorium komputer sekolah, melalui komputer pribadi siswa maupun smartphone siswa tersebut. Dalam tampilan sistem ini dirancang semudah mungkin dalam hal penggunaan dan semenarik mungkin.

Yulianto, Yusuf \& Firmansyah (2019) melaksanakan penelitian dengan judul "Penerapan E-Voting Dengan Metode Waterfall untuk Pemilihan Ketua Osis Pada 
SMP PGRI Parung Panjang Bogo", proses perancangan sistem pada pemilihan ketua OSIS secara e-voting ini menggunakanperancangan ERD (Entity RelationshipDiagram), LRS, Spesifikasi file dan menggunakan basis data MySQL. Penelitian ini bertujuan untuk menyelenggarakan pemungutan suara dengan biaya hemat danperhitungan suara yang cepat dengan menggunakan sistem yang aman dan mudah untuk di lakukan audit. Hasil dari penelitian ini berhasil karena sesuai dengan harapan apa yang ada ditujuan peneliti.

Seiring perkembangan teknologi yang canggih di jaman yang modern ini peneliti ingin mengimplementasikan pemilihan umum yang berbasis website atau yang disebut dengan e-voting. Berdasarkan uraian di atas, hal ini mendorong peneliti untuk melakukan penelitian dengan judul "Rancang Bangun Aplikasi EVoting Berbasis Web Pada Pemilihan Ketua dan Wakil Ketua Osis Di SMK Ibnu Koldun Al Hasyimi”.

E-voting adalah pengambilan suara dengan menggunakan media elektronik atau perangkatelektronik, the council of Europe (CoE), mendefinisikan sebagai sebuah perangkatpemberian suara secara elektronik sehingga memiliki kemampuan untuk mempercepattabulasi data, menekan biaya pemilihan danmemiliki kontribusi untuk mencegah pemilihyang tidak berhak (Risnanto, 2018).

E-voting merupakan suatu alat untuk melakukan pemungutan suara dengan memanfaatkan teknologi, tidak membutuhkan biaya yang banyak dan waktu yang tidak lama untuk mendapatkan informasi yang akurat dalam sebuah pemungutan suara. Dalam penelitian ini dirancang aplikasi $e$-voting yang termasuk dalam jenis internet voting yaitu pemilihan suara melalui media internet, bisa dimana saja seperti dirumah, diperjalanan atau di tempat yang telah disediakan. Website merupakan kumpulan halaman web yang saling terhubung dan file- filenya saling terkait terdiri dari page atau halaman, dan kumpulan halaman yang dinamakan homepage (Isnaini \& Riski, 2019). Website merupakan bentuk aplikasi yang memanfaatkan arsitektur client server. Bentukarsitektur ini, berupa sebuah program client yang terhubung pada server untuk informasi yangdiperlukan guna melengkapi perintah atau tugas tugas yang sudah diatur oleh pengguna. Cara kerja dari client-server arsitektur yaitu client meminta sebuah request layanan terhadap server, kemudianserver akan memproses lalu mengembalikan request kepada 
client. Teknologi web ini memungkinkanuntuk melakukan pengaksesan dari mana saja menggunakan protokol HTTP dan Web Browser (Wulansuci et al., 2018).

PHP Menurut adalah Bahasa Server-Side Scripting yang menyatu dengan HTML untuk membuat halaman web yang dinamis (Iisnaini. S, 2019). MySQL adalah Software atau program aplikasi database, yaitu software yang dapatkita pakai untuk menyimpan data berupa informasi teks juga angka. Database MySQL adalah software database yang tidak memiliki interface (tampilan muka) visual atau berbasis DOS. Perintah dasar MySQL adalah SQL (StructuredQuery Language). Pada penelitian ini dirancang aplikasi $e$-voting berbasi web karena dari kesimpulan pada penelitian sebelumnya diatas, aplikasi dengan $e$-voting sangat memfasilitasi siswa maupun masyarakat dalam memberikan hak suaranya tanpa terkendala ruang dan waktu, selain itu mudah untuk diakses selama ada jaringan internet. Pemilihan berbasis web untuk aplikasi $e$-voting ini menggunakan program yang sama dengan MYSQL, PHP, HTML tetapi yang membedakan nanti aplikasi editor programnya menggunakan sublime textdan diperkuat dengan bukti bahwa penggunaan teknologi untuk mengakses internet sangatlah populer dikalangan masyarakat termasuk siswa. Dalam rencana program e-voting berbasis web SMK Ibnu Kholdun Al Hasyimi ini terdapat beberapa fitur untuk dapat mempermudah siswa/siswi mengakses pemilihan ketua dan wakil ketua osis SMK Ibnu Kholdun Al Hasyimi diantaranya, beranda, foto calon, visi dan misi, dan hasil penghitungan suara pemilihan berbetuk grafik.

\section{METODE}

Jenis penelitian yang digunakan dalam penelitian ini adalah dengan metode riset dan pengembangan $\mathrm{R} \& \mathrm{D}$ (research and development), jenis risetdan pengembangan merupakan metode penelitian yang digunakan untuk menghasilkan produk tertentu dan menguji keefektifan produk tersebut (Sugiyono, 2016:297). Penelitian ini akandikembangkan sistem $e$-voting sebagai alat bantu pemungutan suara bagimasyarakat perantauan.

Menurut Sugiyono (2010), langkah - langkah penelitian dan pengembangan ditunjukkan pada gambar berikut :

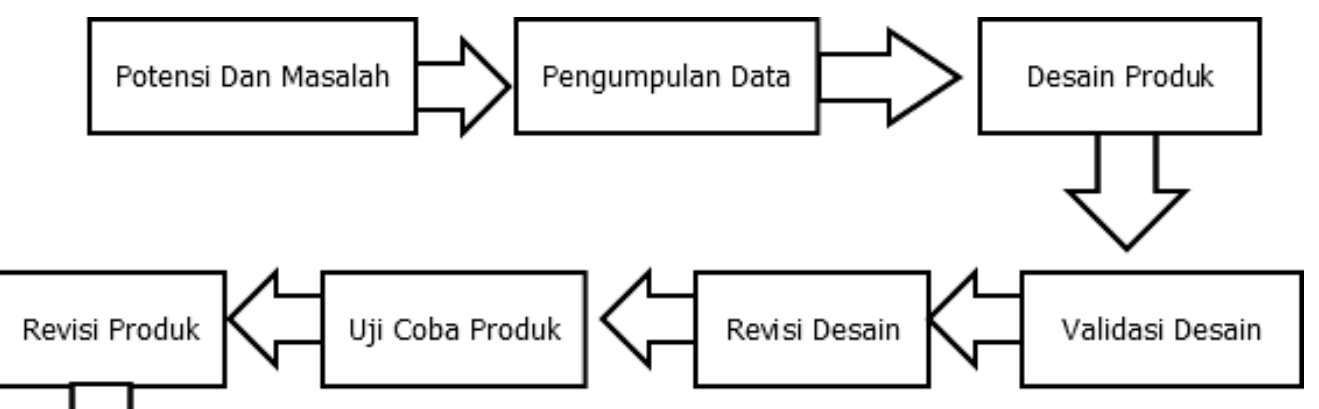




\section{Gambar 1. Langkah-langkah Penggunaan Metode Penelitian dan Pengembangan atau Research and Development $(R \& D)$}

Langkah-langkah proses penelitian dan pengembangan menunjukkan suatu siklus, yang diawali dengan adanya kebutuhan, permasalahan yang membutuhkan pemecahan dengan menggunakan suatu produk tertentu. Dalam penelitian ini metode untuk perancangan sistem yang dipakai yaitu Metode Prototype. Metode protoype merupakan pembuatan model sistem (prototype) yang pengembangan atau pembangunannya dapat dilakukan secara cepat. Metode prototype ini bertujuan untuk mendapatkan gambaran aplikasi yang akan dibangun melalui rancangan aplikasi prototype terlebih dahulu kemudian akan dievaluasi oleh user.

Dalam hal ini peneliti melakukan pengembangan perangkat lunak prototype ini dengan lima tahap, yaitu communication (komunikasi), quick plan (desain cepat), modelling quick design (pemodelan perancangan secara cepat), construction of prototype (pembentukan prototype), dan deployment delevery \& feedback (penyerahan sistem, pengiriman \& umpan balik). (Pressman, 2004).

Kelebihan dari prototype yaitu melibatkan user dalam analisa dan desain, memiliki kemampuan menangkap requirement secara konkret, dan dapat digunakan untuk memperluas SDLC. Sedangkan kekurangan prototype ialah Proses analisis dan perancangan terlalu singkat, mengesampingkan alternatif pemecahan masalah, kurang fleksibel dalam menghadapi perubahan, dan prototype yang dihasilkan tidak selalu mudah untuk diubah dan cepat selesai. Adapun teknik pengumpulan data yang digunakan dalam penelitian ini antara lain observasi, wawancara, angket, dan dokumentasi. Menurut Arifin (2011), observasi adalah suatu proses pengamatan dan pencatatan secara sistematis, logis, objektif dan rasional mengenai berbagai 
fenomena, baik dalam situasi yang sebenarnya maupun dalam situasi buatan untuk mencapai tujuan tertentu. Peneliti melakukan pengamatan di lokasi penelitian guna memperoleh keterangan data yang lebih akurat mengenai hal-hal yang diteliti berupa data terbaru mengenai sistem, kegiatan osis, dan program sekolah yang akan terealisasi di SMK Ibnu Kholdun Al Hasyimi untuk meningkatkan kualitas sekolah tersebut.

Peneliti menggunakan teknik analisis data deskriptif kuantitatif. Data yang diperoleh dari kuisioner/angket, dijumlahkan atau dikelompokkan sesuai dengan bentuk instrumen yang digunakan, disajikan dalam bentuk tabel, lalu dianalisis dan diinterpretasikan (Arikunto, 2006). Analisis kuantitatif diperoleh dari data pengumpulan angket dari programer dan User. Data angket akan dianalisis untuk mendapatkan gambaran tentang sistem e-voting yang digunakan.

Jawaban angket ahli dan user menggunakan skala Likert. Menurut Sugiyono (2013:134), skala Likert digunakan untuk mengukur sikap, pendapat, dan persepsi seseorang atau sekelompok orang tentang fenomena sosial. Angket validitas ahli berisi kisi kisi mengenai kriteria dari media pembelajaran yang dikembangkan. Adapun dalam pengukuran skala Likert variabel yang akan diukur dijabarkan menjadi indikator variabel. Kategori skor dalam skala Likert menurut Putra (2014) dijelaskan pada tabel berikut ini.

Tabel 1. Kategori Skor dalam Skala Likert

\begin{tabular}{|c|c|c|}
\hline No. & Skor & Keterangan \\
\hline 1 & 5 & Sangat Layak \\
\hline 2 & 4 & Layak \\
\hline 3 & 3 & Cukup Layak \\
\hline 4 & 2 & Tidak Layak \\
\hline 5 & 1 & Sangat Tidak Layak \\
\hline
\end{tabular}

Analisis deskriptif dilakukan dengan perhitungan sebagai berikut:

$$
\mathrm{P}=\frac{\sum(\text { seluruh skor } \mathrm{jwb} \text { angket })}{\mathrm{n} \times \text { nilai tertinggi angket } \mathrm{x} \text { jml responden }} \times 100 \%
$$

Keterangan 


\section{P: Persentase Penilaian}

n: Jumlah Seluruh Item Angket

Hasil perhitungan digunakan untuk menentukan kesimpulan atau kategori kelayakan sistem sesuai aspek-aspek yang diteliti, berikut klasifikasi kelayakan yang dibagi rata sesuai dengan 5 kategori pada skala likert. Pembagian rentang kategori kelayakan aplikasi/media.

Tabel 2. Kriteria Kelayakan Produk

\begin{tabular}{|c|c|}
\hline Kategori & Presentase \\
\hline Sangat Layak & $>80 \%-100 \%$ \\
\hline Layak & $>60 \%-80 \%$ \\
\hline Cukup Layak & $>40 \%-60 \%$ \\
\hline Tidak Layak & $>20 \%-40 \%$ \\
\hline Sangat Tidak Layak & $0 \%-20 \%$ \\
\hline
\end{tabular}

Alat penelitian yang digunakan pada penelitian ini terdiri dari hardware dan software. Spesifikasi hardware yang layak digunakan yaitu laptop/komputer dengan prosesor Intel(R) Pentium(R) CPU @2.40 GHz, RAM sebesar 2 GB DDR3, dan kapasitas hard drive/hardisk sebesar 500 GB. Sedangkan spesifikasi software yang dapat digunakan ialah sistem operasi Windows 7 Ultimate 32 bit dan web browser dengan google chrome dan mozilla firefox.

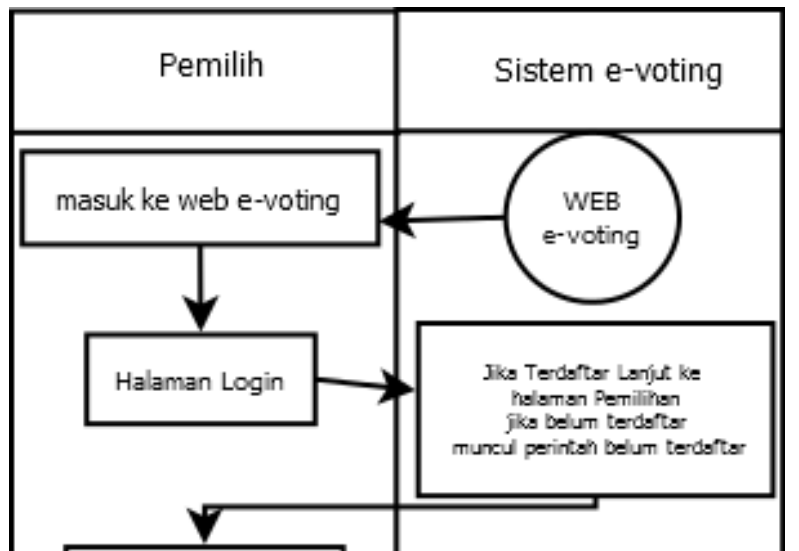




\section{Gambar 2. Flowchart Alur Kerja Sistem E-voting}

\section{HASIL DAN PEMBAHASAN}

\section{Hasil}

Penelitian dilakukan di SMK Ibnu Kholdun Al Hasyimi dengan menggunakan jaringan wifi dan jaringan seluler di setiap kelas bagi yang memiliki smartphone dan laptop, bagi siswa/siswi yang bermukim di pondok di sediakan suatu ruangan untuk melakukan pemilihan yang sudah disediakan oleh sekolah. Waktu pelaksanaan pemilihan dan penggunakan sistem e-voting pemilihan ketua dan wakil ketua osis SMK Ibnu Kholdun Al Hasyimi dilaksanakan tanggal 19 Agustus 2020, pukul 08.00 - 11.00 WIB.

Setelah tahap-tahap dalam prototype dilakukan diantaranya analisa kebutuhan sistem, desain sistem dan coding, maka langkah selanjutnya adalah melakukan tahap pengujian sistem. Pada tahap pengujian sistem ini penulis melakukan pengujian terhadap setiap fungsi-fungsi yang ada. Metode pengujian yang digunakan yaitu metode black box testing dengan metode error guessy, dimana pengujian dilakukan berfokus pada persyaratan fungsional sistem.

Tabel 3. Hasil Pengujian (Blackbox Testing)

\begin{tabular}{|c|c|c|c|c|}
\hline No. & Pengujian & $\begin{array}{c}\text { Skenario } \\
\text { Pengujian }\end{array}$ & $\begin{array}{c}\text { Hasil yang } \\
\text { diharapkan }\end{array}$ & Hasil \\
\hline
\end{tabular}




\begin{tabular}{|c|c|c|c|c|}
\hline 1. & $\begin{array}{l}\text { Fungsi login } \\
\text { pemilih }\end{array}$ & $\begin{array}{l}\text { Pemilih } \\
\text { (siswa/siswi) } \\
\text { login dengan } \\
\text { NIS yang sudah } \\
\text { terdaftar. }\end{array}$ & $\begin{array}{l}\text { Pemilih } \\
\text { (siswa/siswi) } \\
\text { berhasil masuk } \\
\text { kehalaman pemilih. }\end{array}$ & Berhasil \\
\hline 2. & $\begin{array}{l}\text { Fungsi visi \& } \\
\text { misi kandidat } \\
\text { paslon ketua } \\
\text { dan wakil } \\
\text { ketua osis }\end{array}$ & $\begin{array}{l}\text { Pemilih } \\
\text { (siswa/siswi) } \\
\text { melihat visi \& } \\
\text { misi setiap } \\
\text { paslon. }\end{array}$ & $\begin{array}{l}\text { Pemilih } \\
\text { (siswa/siswi) dapat } \\
\text { melihat halaman visi } \\
\& \text { misi kandidat } \\
\text { paslon. }\end{array}$ & Berhasil \\
\hline 3. & $\begin{array}{l}\text { Fungsi beri } \\
\text { pilihan } \\
\text { kandidat } \\
\text { paslon ketua } \\
\text { dan wakil } \\
\text { ketua osis }\end{array}$ & $\begin{array}{l}\text { Pemilih } \\
\text { (siswa/siswi) } \\
\text { memberi pilihan } \\
\text { kepada kandidat } \\
\text { paslon. }\end{array}$ & $\begin{array}{l}\text { Pemilih } \\
\text { (siswa/siswi) dapat } \\
\text { memberikan pilihan } \\
\text { kepada kandidat } \\
\text { paslon yang di } \\
\text { kehendaki. }\end{array}$ & Berhasil \\
\hline 4. & $\begin{array}{l}\text { Fungsi } \\
\text { tombol } \\
\text { kembali ke } \\
\text { beranda }\end{array}$ & $\begin{array}{l}\text { Pemilih } \\
\text { (siswa/siswi) } \\
\text { kembali ke } \\
\text { beranda login e- } \\
\text { voting. }\end{array}$ & $\begin{array}{l}\text { Pemilih } \\
\text { (siswa/siswi) dapat } \\
\text { kembali ke bernda } \\
\text { login e-voting. }\end{array}$ & Berhasil \\
\hline 5. & $\begin{array}{l}\text { Fungsi login } \\
\text { administrator }\end{array}$ & $\begin{array}{l}\text { Administrator } \\
\text { login dengan } \\
\text { input username } \\
\text { dan password. }\end{array}$ & $\begin{array}{l}\text { Administrator } \\
\text { berhasil masuk ke } \\
\text { halaman menu } \\
\text { admin. }\end{array}$ & Berhasil \\
\hline 6. & $\begin{array}{l}\text { Fungsi } \\
\text { tambah, edit } \\
\text { dan hapus } \\
\text { kandidat } \\
\text { paslon }\end{array}$ & $\begin{array}{l}\text { Administrator } \\
\text { menambah, edit } \\
\text { dan menghapus } \\
\text { kandidat paslon. }\end{array}$ & $\begin{array}{l}\text { Administrator dapat } \\
\text { menambah, edit dan } \\
\text { menghapus kandidat } \\
\text { paslon. }\end{array}$ & Berhasil \\
\hline 7. & $\begin{array}{l}\text { Fungsi } \\
\text { tambah, edit } \\
\text { dan hapus } \\
\text { kelas }\end{array}$ & $\begin{array}{l}\text { Administrator } \\
\text { menambah, edit } \\
\text { dan menghapus } \\
\text { kelas }\end{array}$ & $\begin{array}{l}\text { Administrator dapat } \\
\text { menambah, edit dan } \\
\text { menghapus kelas }\end{array}$ & Berhasil \\
\hline 8. & $\begin{array}{l}\text { Fungsi } \\
\text { tambah, edit } \\
\text { dan hapus } \\
\text { data pemilih }\end{array}$ & $\begin{array}{l}\text { Administrator } \\
\text { menambah, edit } \\
\text { dan menghapus } \\
\text { data pemilih }\end{array}$ & $\begin{array}{l}\text { Administrator dapat } \\
\text { menambah, edit dan } \\
\text { menghapus data } \\
\text { pemilih }\end{array}$ & Berhasil \\
\hline
\end{tabular}




\begin{tabular}{|c|c|c|c|c|}
\hline 9. & $\begin{array}{l}\text { Fungsi } \\
\text { perolehan } \\
\text { pilihan dan } \\
\text { simpan hasil } \\
\text { perolehan } \\
\text { pilihan }\end{array}$ & $\begin{array}{l}\text { Administrator } \\
\text { melihat dan } \\
\text { menyimpan } \\
\text { hasil perolehan } \\
\text { pilihan }\end{array}$ & $\begin{array}{l}\text { Administrator dapat } \\
\text { melihat dan } \\
\text { menyimpan hasil } \\
\text { perolehan pilihan }\end{array}$ & Berhasil \\
\hline 10. & $\begin{array}{l}\text { Fungsi edit } \\
\text { profil admin }\end{array}$ & $\begin{array}{l}\text { Administrator } \\
\text { merubah profil } \\
\text { admin }\end{array}$ & $\begin{array}{l}\text { Administrator dapat } \\
\text { merubah profil } \\
\text { admin }\end{array}$ & Berhasil \\
\hline 11. & $\begin{array}{l}\text { Fungsi ganti } \\
\text { password } \\
\text { admin }\end{array}$ & $\begin{array}{l}\text { Administrator } \\
\text { merubah } \\
\text { password admin }\end{array}$ & $\begin{array}{l}\text { Administrator dapat } \\
\text { mengganti password }\end{array}$ & Berhasil \\
\hline 12. & $\begin{array}{l}\text { Fungsi } \\
\text { tombol keluar } \\
\text { dan beranda }\end{array}$ & $\begin{array}{l}\text { Administrator } \\
\text { keluar dan } \\
\text { kembali ke } \\
\text { beranda }\end{array}$ & $\begin{array}{l}\text { Administrator dapat } \\
\text { keluar dan kembali } \\
\text { keberanda jika sudah } \\
\text { melakukan } \\
\text { pemutakhiran data }\end{array}$ & Berhasil \\
\hline 13. & $\begin{array}{l}\text { Fungsi menu } \\
\text { dan navigasi }\end{array}$ & $\begin{array}{l}\text { Administrator } \\
\text { mencoba menu } \\
\text { dan navigasi di } \\
\text { dalam sistem }\end{array}$ & $\begin{array}{l}\text { Administrator dapat } \\
\text { masuk ke halaman } \\
\text { yang sesuai dengan } \\
\text { menu dan navigasi } \\
\text { yang pilih }\end{array}$ & Berhasil \\
\hline 14. & $\begin{array}{l}\text { Fungsi pesan } \\
\text { error }\end{array}$ & $\begin{array}{l}\text { Administrator } \\
\text { mencoba input } \\
\text { data yang tidak } \\
\text { sesuai dengan } \\
\text { kriteria dalam } \\
\text { database sistem }\end{array}$ & $\begin{array}{l}\text { Administrator } \\
\text { melihat pesan error } \\
\text { saat input data yang } \\
\text { tidak sesuai dengan } \\
\text { kriteria dalam } \\
\text { database sistem }\end{array}$ & Berhasil \\
\hline 15. & $\begin{array}{l}\text { Sistem } \\
\text { menampilkan } \\
\text { data dari hasil } \\
\text { input }\end{array}$ & $\begin{array}{l}\text { Administrator } \\
\text { mencoba input } \\
\text { data sesuai } \\
\text { kriteria sistem }\end{array}$ & $\begin{array}{l}\text { Administrator dapat } \\
\text { melihat daftar atau } \\
\text { halaman sesuai data } \\
\text { yang diinput }\end{array}$ & Berhasil \\
\hline
\end{tabular}

Hasil perolehan skor angket uji kelayakan oleh pengguna (user) disajikan pada tabel dibawah ini :

Tabel 4. Perolehan Skor Hasil Uji Lapangan Oleh Pemilih/User 


\begin{tabular}{|c|c|c|c|c|c|c|c|c|c|c|c|c|c|c|c|}
\hline \multirow{2}{*}{ No } & \multirow{2}{*}{ Nama Pemilih } & & & & & & & & & & & & & & \multirow{2}{*}{ Jumlah } \\
\hline & & 1 & 2 & 3 & 4 & 5 & 6 & 7 & 8 & 9 & 10 & 11 & 12 & 13 & \\
\hline 1. & Syaiful Hasan, S.Pd & 4 & 3 & 3 & 5 & 4 & 5 & 4 & 3 & 4 & 4 & 5 & 5 & 4 & 53 \\
\hline 2. & Ma'rifatul Hasanah & 4 & 4 & 5 & 5 & 3 & 5 & 4 & 5 & 3 & 4 & 5 & 4 & 5 & 56 \\
\hline 3. & Muh. Dani Raehan & 4 & 3 & 5 & 5 & 4 & 4 & 5 & 3 & 5 & 5 & 4 & 3 & 5 & 55 \\
\hline 4. & $\begin{array}{l}\text { Muzayyanatul } \\
\text { Hasanah }\end{array}$ & 4 & 5 & 3 & 5 & 4 & 5 & 3 & 5 & 3 & 4 & 5 & 4 & 5 & 55 \\
\hline 5. & Nur Halimah & 5 & 4 & 5 & 3 & 4 & 5 & 5 & 4 & 5 & 3 & 4 & 5 & 5 & 57 \\
\hline 6. & $\begin{array}{l}\text { Muhammad Fatih } \\
\text { Alfas }\end{array}$ & 5 & 5 & 3 & 5 & 3 & 5 & 3 & 4 & 5 & 3 & 3 & 4 & 5 & 53 \\
\hline 7. & Abdul Gafur & 3 & 4 & 5 & 4 & 3 & 5 & 4 & 5 & 4 & 3 & 4 & 5 & 5 & 54 \\
\hline \multicolumn{2}{|c|}{ Jumlah Item Angket } & 29 & 28 & 29 & 32 & 25 & 34 & 28 & 29 & 29 & 26 & 30 & 30 & 34 & 383 \\
\hline \multicolumn{2}{|c|}{ Jumlah Keseluruhan Item } & \multicolumn{14}{|c|}{383} \\
\hline
\end{tabular}

Data penelitian yang disajikan dalam bentuk kuantitatif berdasarkan item yang sudah terdapat pada angket uji kelayakan oleh pemilih/user dan akan di analisis untuk mengetahui hasil kelayakan sistem e-voting pemilihan ketua dan wakil ketua osis SMK Ibnu Kholdun Al Hasyimi.

Analisis data yang di dapat dari angket uji kelayakan oleh pemilih/user dilakukan dengan perhitungan sebagai berikut :

$$
\begin{aligned}
& \mathrm{P}=\frac{\sum(383)}{13 \times 5 \times 7} \times 100 \% \\
& \mathrm{P}=\frac{\sum(38300)}{455} \%=84,17 \%
\end{aligned}
$$

Berdasarkan data penghitungan diatas, maka dapat di ketahui skor akhir dari pengujian uji kelayakan pada sistem e-voting berbasis web pada pemilihan ketua dan wakil ketua osis di SMK Ibnu Kholdun Al Hasyimi dengan jumlah nilai persentase penilaian $84,17 \%$ jika di kriteria kelayakan produk yaitu masuk kategori sangat layak.

\section{Pembahasan}

Berdasarkan metode pengujian black box testing dengan metode error guessy yang mana sudah di jelasakan bahwa metode ini hanya di lakukan oleh seorang programer atau orang yang membuat rancang bangun tersebut, sehingga pengujian pada sistem e-voting ini fokus pada jalannya sistem tersebut. Dan untuk mengetahui kelayakan sistem e-voting berbasis web di SMK Ibnu Kholdun Al Hasyimi ini 
menggunakan uji kelayakan oleh user/pemilih yang mana pemilih atau user tersebut sudah pernah menggunakan sistem e-voting ini, yaitu dengan sampel 7 user/pemilih dari setiap kelas atau kelompok di SMK Ibnu Kholdun Al Hasyimi.

Setelah pengujian black box selesai maka sistem e-voting yang sudah dinyatakan berhasil dan sudha siap dipakai dan selanjutnya dapat di lakukan uji lapangan pada pemilihan ketua dan wakil ketua osis di SMK Ibnu Kholdun Al Hasyimi, setelah pemilihan tersebut maka di lakukan penyebaran angket kepada user/pemilih dan dari bukti dan seluruh angket yang sudah terkumpul selajutnya dihitung menggunakan rumus yang sudah di jelaskan dalam penelitian ini. Setelah dilakukan uji kelayakan dilapangan dan hasil akhir dari penghitungan uji kelayakan dari angket user/pemilih maka mendapatkan hasil $84,17 \%$ yang mana jika dikategorikan dalam tabel kriteria kelayakan produk yaitu masuk dalam persentase rentang nilai $>80 \%-100 \%$ yang masuk dalam kategori sangat layak.

Sistem e-voting berbasis web pada pemilihan ketua dan wakil ketua osis terbukti berpengaruh dan efektif pada pemilihan periode 2020/2021 yang mana pada saat penerapan, siswa/siswi cenderung lebih aktif dalam mengikuti pemilihan ketua dan wakil ketua osis dan sistem e-voting ini dinilai sangat baru dikalangan siswa/siswi sehingga dalam melakukan pemilihan siswa/siswi lebih cepat dalam melakukan kegiatan tersebut dan tidak mengganggu aktifitas dan waktu yang cukup lama dalam memberi pilihan. Hasil dari pemilihan langsung dapat dilihat dan dapat langsung diumumkan kepada user/pemilih kandidat paslon yang memperoleh hasil terbanyak dari pemilihan tersebut.

\section{SIMPULAN}

Berdasarkan hasil penelitian dan pembahasan, maka kesimpulan yang dapat diambil dari penelitian ini yaitu sistem e-voting berbasis web pada pemilihan ketua dan wakil ketua osis di SMK Ibnu Kholdun Al Hasyimi ini telah berhasil dikembangkan. Sistem ini dapat membantu lancarnya pemilihan ketua dan wakil ketua osis periode 2020/2021 dengan baik dan lancar. berdasarkan uji kelayakan yang dilakukann oleh pemilih/user, tingkat kelayakan sistem e-voting berbasis web pada pemilihan ketua dan wakil ketua osis di SMK Ibnu Kholdun Al Hasyimi adalah sangat layak. 
Adapun saran penulis dalam penelitian ini ialah diperlukan adanya beberapa penambahan beberapa fitur seperti penggunaan password login user, daftar hadir pemilih, dan hasil penghitungan suara yang dapat disimpan dalam berbagai fromat file. Selain itu juga dibutuhkan sistem keamanan yang lebih kuat agar tidak ada pemilih yang curang.

\section{DAFTAR RUJUKAN}

Arikunto, Suharsimi. 2006. Prosedur Penelitian : Suatu Pendekatan Praktik(Edisi Revisi VI). Jakarta : Rineka Cipta.

Iisnaini, S., \& Riski, B. (2019). APLIKASI E-VOTE PEMILIHAN PRESIDEN BADAN EKSEKUTIF MAHASISWA ( BEM ) AMIK DIAN CIPTA CENDIKIA BANDAR LAMPUNG BERBASIS WEB. 2, 27-36.

Ikhwani, Y. (2018). Analisis Dan Rancangan Sistem E-Voting Pemilihan Ketua Osis. Technologia, 9(3), 138-143.

Ismail, M. (2017). Aplikasi E-Voting Pemilihan Kepala Desa Di Kecamatan Botupingge Berbasis Web. JTII (Jurnal Teknologi Informasi Indonesia), 2(2), $25-31$.

Margono. 2009. Metodologi Penelitian Pendidikan. Jakarta : Rineka Cipta.

Purba, M. M. (2014). Perancangan E-Voting Untuk Pemilihan Bem Berbasis Web. Jurnal Sistem Informasi Universitas Suryadarma, 5(2), 160-170. https://doi.org/10.35968/jsi.v5i2.245

Risnanto, S. (2018). Aplikasi Pemungutan Suara Elektronik/E-Voting Menggunakan Teknologi Short Message Service Dan At Command. Jurnal Teknik Informatika, 10(1), 17-26. https://doi.org/10.15408/jti.v10i1.6811

Ristiani, V., Hermaliani, E. H., \& Utami, D. Y. (2019). Sistem Informasi E-Voting Untuk Pemilihan Ketua OSIS Di SMK Strada II Jakarta. 4(1), 1-10.

Sugiyono. 2016. Metode penelitian Kuantitatif, Kualitatif, dan R\&D. Bandung : Alfabeta.

Wijaya, H. O. L. 2017. E-Voting Berbasis Website Pada Pemilihan Kades Di Rantau Jaya (Lake) Dengan Keamanan Data Menggunakan Enkripsi Base 64. Jurasik (Jurnal Riset Sistem Informasi Dan Teknik Informatika), 2(1), 48. https://doi.org/10.30645/jurasik.v2i1.18

Wulansuci, R., Rakhman, A., \& Salamah, I. (2018). Perancangan Alat E-Voting 
Untuk Pemilihan Umum. 65-69.

Yulianto, A., Yusuf, D. H., \& Firmansyah. (2019). Penerapan E-Voting Dengan Metode Waterfall Untuk Pemilihan Ketua Osis Pada SMP PGRI Parung Panjang Bogor. Riset dan E-Jurnal Manajemen Informatika Komputer, 3(2), $66-73$.

Retrieved from https://jurnal.polgan.ac.id/index.php/remik/article/view/10117/237.

Yusuf, E. M., \& Kaniawulan, I. (2015). Pengembangan Prototipe Sistem Informasi Geografis Fasilitas Olahraga Berbasis Mobile (Studi Kasus Fasilitas Olahraga Di Kecamatan Purwakarta) Program Studi Teknik Informatika Sekolah Tinggi Teknologi Wastukancana Jalan Raya Cikopak Sadang No 54 Purwakarta. Riau Journal Of Computer Science, 1(1), 57-68. 